\title{
Enhanced Antibiofilm Activity of Endophytic Bacteria Mediated Zirconium Nanoparticles
}

\author{
Sowmya Balaji 1 ${ }^{(\mathbb{D})}$, Venkat Kumar Shanmugam ${ }^{1, *}$ (D) \\ 1 School of Biosciences and Technology, VIT University, Vellore - 632014, TN; venkatkumars@ vit.ac.in-mail (V.K.S.); \\ * Correspondence: venkatkumars@ vit.ac.in-mail (V.K.S.);
}

Scopus Author ID 51462272000

Received: 10.03.2021; Revised: 4.04.2021; Accepted: 8.04.2021; Published: 19.04.2021

\begin{abstract}
Unraveling the biofilm formation of oral pathogens by endophytic bacteria-mediated zirconia nanoparticles promotes to exhibits as a dental restorative agent by enhancing antibiofilm activity. To demonstrate the mechanistic studies of biogenic zirconium nanoparticle restricts the growth of oral pathogens. The endophytic bacteria isolated from Terminalia chebula have valuable secondary metabolites used as reducing agents for the synthesis of zirconia nanoparticles. Characterization studies were done for the application of dental restorative material. The nanospheres' shape and size were confirmed by SEM/EDAX followed by XRD and FTIR for their chemical groups that contribute as the antagonist for biofilm. Parallelly evaluation of antioxidant, antibacterial, anti-inflammatory, and antibiofilm activity is opposing the disease-causing pathogens and examined for biocompatibility on Human Primary Gingival fibroblast cell lines. Therefore, the endophytic bacteria mediated zirconia nanoparticles were biologically assessed against oral pathogens, promoting results to exhibit dental restorative biomaterial.
\end{abstract}

Keywords: antibiofilm activity; endophytic bacteria; Terminalia chebula; zirconia nanoparticle; human gingival fibroblast cell lines (HGF).

(C) 2021 by the authors. This article is an open-access article distributed under the terms and conditions of the Creative Commons Attribution (CC BY) license (https://creativecommons.org/licenses/by/4.0/).

\section{Introduction}

The scope to formulate matter, devices, and methods by atomic precision is known as nanotechnology [1]. Recently, nanotechnology has handled different physics, chemistry, material science, and biotechnology approaches to develop materials that retain peculiar characteristics as its conviction of structures on the nanometre scale. Nanobiotechnology plays a vital role as bio implant materials and a promising drug delivery system. Nanoparticles have remarkable properties like antibacterial activity, high thermal conductivity, high oxidation resistance, and enhanced corrosive-resistance property [2]. Compared with microparticles, the Nanoparticles are reliable and possess a higher surface area when relating to volume and density. Zirconium oxide is a form of ceramic-based nanoparticles with a wide range of applications, including artificial gemstones, deodorants, oxygen sensors, catalyst supports, furnace bricks, and abrasive applications [3]. In the biological synthesis of nanoparticles, green plants, fruits, and seeds were used to obtain the phytochemical properties to be capped on the nanoparticle. Besides, microbes and microbial byproducts were utilized, and the percentage of the release of a hazardous substance into nature remains null [4]. Thus the green method of synthesis has cost-effective manner and reproducible [5,6]. Terminalia chebula is the scientific name of Kadukai, a common name in Tamil that has rich secondary metabolites that were 
extensively utilized to treat diabetes milletus, skin disorders, and oral hygiene [7]. Terminalia chebula belongs to South Asia. In Ayurveda, Kadukai is proposed for leading a long healthy life and termed as multipurpose herb, which includes the digestive tract's cleansing; elimination of bacteria, worms, and parasites prolonged existence leads to cancer effect in the human body $[8,9]$. The endophytes present Terminalia chebula was less explored, and the fungal species are known for the synthesis of nanoparticles [10,11] and have potent biological activity. Compared to that of extract of seed as reducing agent, the synthesis method was examined to treat the oral pathogens present in the human oral cavity, which causes biofilm-mediated disease [11,12]. Examples of oral pathogens include anaerobic bacteria such as Arachnia, Actinomyces, Bacteroides, etc. [13]. Dental caries and periodontitis are some of the oral diseases caused when there is an imbalance in $\mathrm{pH}$, extracellular polysaccharides, and antibiotic resistance $[14,15]$. This study focus on the Zirconium nanoparticle synthesized by endophytic bacteria against biofilm formation pathogens and evaluated for its biocompatibility on Human Gingival fibroblasts cell line.

\section{Materials and Methods}

\subsection{Isolation of endophytes.}

Terminalia chebula, common name Kadukai seed, was collected from Amarti forest in the Vellore region, Tamil Nadu, India. Surface sterilization was done for the collected samples with a slight modification of the procedure [16]. $4 \%$ of sodium hypochlorite solution was used to rinse the seeds, followed by $70 \%$ ethanol wash and dried in sterile condition and then transferred into tryptic soy agar medium by incubating for 5 days at $37^{\circ} \mathrm{C}$ [17]. The colonies were selected by biochemical method and identified by molecular sequencing. The potent strain was submitted in the GenBank database of the National Centre of Biotechnology Information (NCBI) with accession id: SUB5320944 Bacillus niacini was used to synthesize zirconium oxide nanoparticles [18].

\subsection{Biogenic zirconium nanoparticles.}

Zirconium oxychloride $\left(\mathrm{ZrOCl}_{2} \cdot 8 \mathrm{H}_{2} \mathrm{O}\right)$ was taken as a precursor $2 \mathrm{mM}$ was dissolved in $100 \mathrm{ml}$ of culture containing Bacillus niacini and kept under the stirrer for $8 \mathrm{~h}$ at $1000 \mathrm{rpm}$ in $60^{\circ} \mathrm{C}$ this was mentioned as SV2 method. The Zirconium oxide nanoparticle was synthesized by extract of Terminalia chebula seeds of about $60 \mathrm{ml}$ of extract was mixed with $40 \mathrm{ml}$ of the same concentration dissolved in MilliQ water and placed in magnetic stirrer with $80^{\circ} \mathrm{C}$ for at $600 \mathrm{rpm} 10 \mathrm{~h}$, which was mentioned as SV1 [19]. The nutrient present in the medium acts as a supplement and enhancement agent for bacteria and sucrose growth and enzymes act as catalysts for the reaction process. This was assessed once every hour by UV readings range 200-800 nm to synthesize zirconium oxide nanoparticles [20,21]. After the reaction progressed, the solutions were centrifuged to get cell-free nanoparticles by washing the pellets with $70 \%$ ethanol twice and placed in a hot air oven at $50^{\circ} \mathrm{C}$ for $24 \mathrm{~h}$. The fine powder was taken for biological evaluation [22]. 


\subsection{Experiment studies.}

The biogenic zirconium nanoparticles synthesized via green synthesis was confirmed by characterization method such as UV-visible spectrum, FTIR, XRD, SEM and EDAX After all this characterization, the sample was further analyzed for biocompatibility [23,24].

\subsection{Biofilm activity.}

The oral pathogenic strains, including Escherichia coli, Klebsiella aerogenes, Proteus vulgaris, Streptococcus mutant, and Staphylococcus aureus, were gifted from Kalvi dental clinic Konavattam Vellore region, Tamil Nadu. All the strains were subcultures in a selective medium. With McFarland standards, the culture stock was prepared with Luria bertin broth of about $10 \mathrm{~mL}$, in which $10 \mu \mathrm{L}$ of culture was added and incubated at $37^{\circ} \mathrm{C}$ for $48 \mathrm{~h}$. The matured culture was then diluted to 10 -fold in the growth medium to form biofilm in a 24-well plate, 1 $\mathrm{mL}$ was seed, and with various concentration of $20,40,60 \mu \mathrm{L}$ of Biogenic zirconium nanoparticle were made up to $1 \mathrm{ml}$ was added and incubated $37^{\circ} \mathrm{C}$ for $72 \mathrm{~h}$ to form mature biofilms. After incubation, the broth was removed and added with $0.5 \%$ phosphate buffer saline to get free from cell debris and rinsed twice, followed by $0.1 \%$ crystal violet, this was leftover for $10 \mathrm{~min}$, and then stain was removed by $70 \%$ ethanol to takeoff excess dye. Then, $4 \%$ glacial acetic acid was added, and OD (optical density) was measured after $15 \mathrm{~min}$ at $540 \mathrm{~nm}$ using an ELISA reader [25,26].

\subsection{MTT assay.}

$200 \mu \mathrm{l}$ of human gingival fibroblasts cell suspension was seeded in a 96-well plate at required cell density (20,000 cells per well), without the test agent, and incubated for $24 \mathrm{~h}$. About $40 \mu \mathrm{l}$ of zirconium nanoparticles were added and allowed for $24 \mathrm{~h}$ at $37^{\circ} \mathrm{C}$ in a $5 \% \mathrm{CO} 2$ atmosphere to the cell line. After the incubation period, media was removed, and MTT reagent was added and followed by $100 \mu \mathrm{L}$ of solubilization solution DMSO [27]. Stirring was done in a gyratory shaker which promotes dissolution of MTT formazan crystals in cell culture. An ELISA reader took the absorbance at $630 \mathrm{~nm}$ used as reference wavelength [28].

\section{Results and Discussion}

\subsection{UV-Visible spectrometry.}

In Figure 1, UV-Visible spectrometry reveals the biogenic zirconium oxide nanoparticle's spectral pattern from Terminalia chebula at the peak range between 200-1000 $\mathrm{nm}$. The standard zirconium oxide was used as the reference for the characterization studies that emit at $235 \mathrm{~nm}$. In contrast, biogenic zirconium oxide nanoparticle (SV1) from seed extract of Terminalia chebula emit peaks at $260 \mathrm{~nm}$ [29], and another synthesized zirconium nanoparticle (SV2) from endophyte Bacillus niacin emits at the peak of $290 \mathrm{~nm}$ at $5 \mathrm{~h}$ [30]. From this synthesis pattern, the synthesis process factors were influenced and enhanced the product formation. The metabolites in endophytic bacteria give an expeditious response when compared with seed extract $[21,31]$. 


\section{UV-Vis}

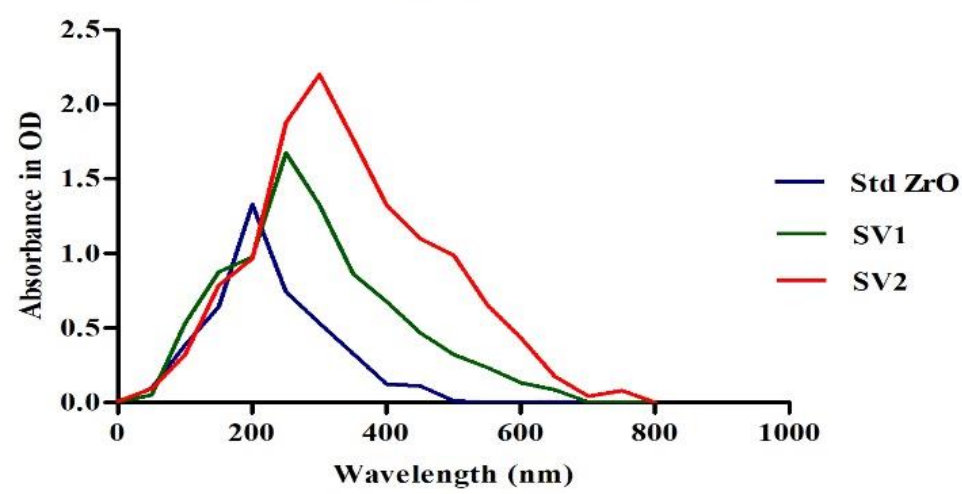

Figure 1. The spectral pattern reveals the speak emitted for SV1, SV2, and Std ZrO.

\subsection{XRD.}

In Figure 2, the XRD pattern of synthesized biogenic zirconium nanoparticles was compared with JCPDS - 79-1771 reveals that the grain size differs from the synthesis pattern [32]. Crystalite size of the nanoparticle was found to be $15.52 \mathrm{~nm}$ for the SV1 method due to the phytochemicals present in the seed extract, and it reduces the charge and stability [33], whereas $60 \mathrm{~nm}$ size for SV- 2, bacteria uptakes the nutrients and produces the secondary metabolites which enhance the product formation with aggregation, after the calcination process the synthesized zirconium nanoparticles are reduced in size. This can be achieved by at high temperature in muffle furnace then the particles become fine powder with no aggregation [34].

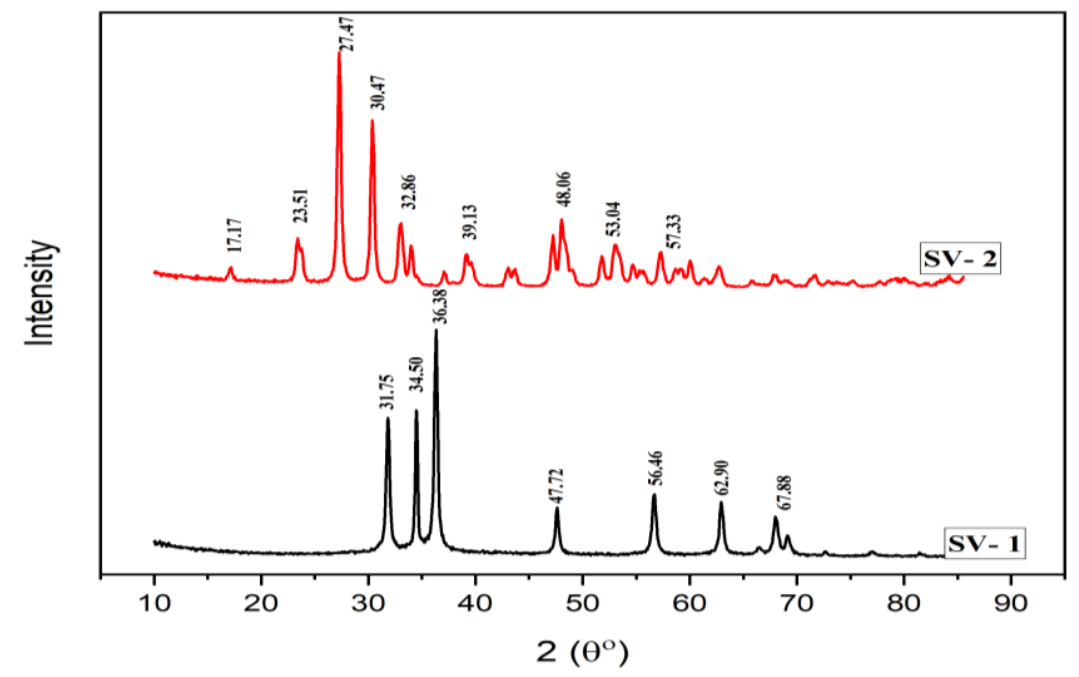

Figure 2. The XRD graph representation for size of biogenic zirconium oxide and nanoparticle.

\subsection{FTIR.}

In Figure 3, FTIR spectral patterns represent the standard zirconium oxide and SV1 for the green synthesis of zirconium oxide nanoparticles by seed extract. For std, the peak of 673.36 and 746.26 refers to the zirconia metal, and 3438.40 represents oxide. In the SV1 spectral band, the extract acts as a capping agent, and the phytochemicals like alkaloids, flavonoids, phenols, carbohydrates, glycosides, terpenoid, saponin, and acids enhance the formation of the nanoparticles bands at 3327.73 gives the $\mathrm{OH}$ stretch [35], 1610.56, 1383.06, 1249.50, 1100.02, 1012.40 corresponds to alcohol/phenol $\mathrm{O}-\mathrm{H}$ stretch, aromatic $\mathrm{C}=\mathrm{C}$ bending, aromatic $\mathrm{C}-\mathrm{H}$ bending and aliphatic iodine compound [29]. For SV2 spectral pattern indicates at 3292.49, 
1610.56, 2871.01, and 2713.76 prominent to $\mathrm{CH}_{2}$. 2434.61 and 2027.01 due to vibration of $\mathrm{C}=\mathrm{C}-$ the stretch of alkenes and 1541.17 aromatic $\mathrm{C}=\mathrm{C}$ bending with aromatic $\mathrm{C}-\mathrm{H}$ bending 669.13 attributes for aryl disulfides [36].

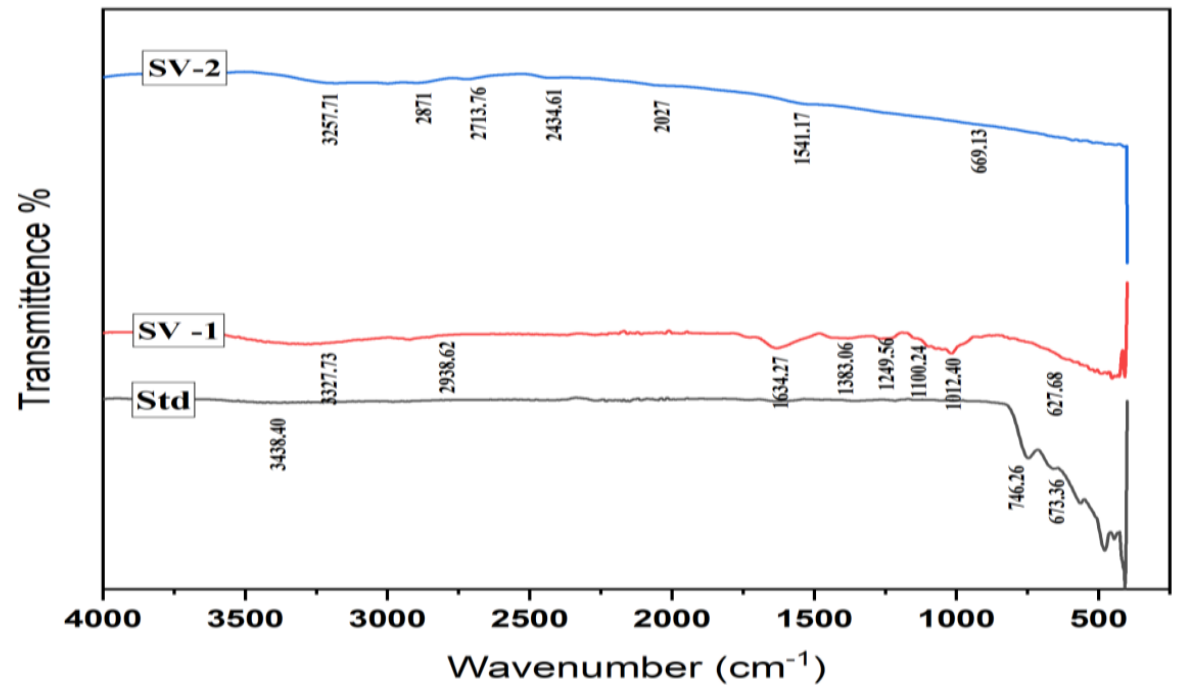

Figure 3. FTIR spectrum for biogenic zirconium nanoparticle.

\subsection{SEM/EDAX.}

In Figure 4 (a), the synthesized zirconium oxide nanoparticles are eventually distributed in the SEM image with no aggregation. The phytochemicals that are responsible for the reducing agent result in the formation of the oxide nanoparticles, whereas in (b) promptly occurrences with evenly shape was due to the bacterial conjugation of metal-binding sites to the precursor and the production of acids from Bacillus sp enhances the synthesis pattern of the nanoparticles. In (c), there was evidence of elements present in the synthesized nanoparticles with zirconia, carbon groups, and oxygen groups were equally distributes $[37,38]$.

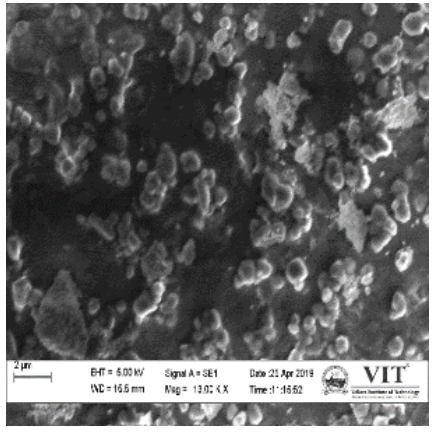

(a)

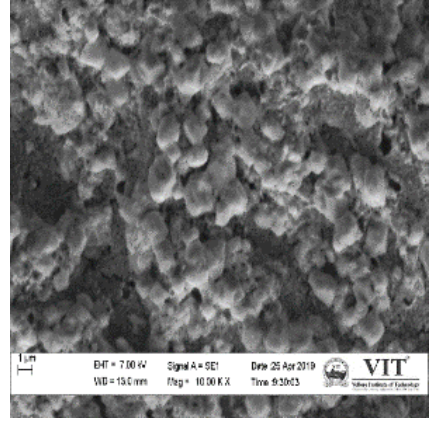

(b)

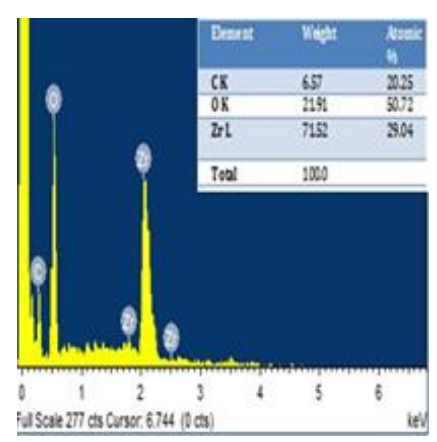

(c)

Figure 4. (a) SEM of SV1; (b)SEM of SV2; (c) EDAX.

\subsection{Antibiofilm activity.}

In Table 1, the oral pathogens show significant removal of biofilm formation when treated with a respective concentration of $40 \mu \mathrm{g} / \mathrm{mL}$ of zirconium nanoparticles SV2 compared to that of zirconium oxide nanoparticle SV1 for E.coli $81 \%$ of biofilm removal and $91.5 \%$, similarly prominent results obtain for the virulent strain S.aureus $92.5 \%$ removal of biofilm treated with SV2 and $80.5 \%$ of SV1. The commonly existing pathogenic microbial strain was S. mutant has $90.5 \%$ removal when treated with SV2 and $83.5 \%$ when subjected to SV1. At 
higher concentrations, the viability of the cell may lead to a toxic effect [39]. The exopolysaccharides were responsible for induced biofilm formation with the receptor [40] glucan-binding domains of glucosyltransferase play a vital role in forming biofilms by glucan binding proteins in virulent strains of S.aures and S.mutant [41]. In some adverse conditions, the exuberance of pathogenic resistance on antibiotics reoccurrence occurs and may lead to rapid cell growth in the oral tissues [42]. This can be addressed using medication with natural products and the combination of the dual role by direct contact killing of pathogens as well as the release of ionic by the capped agents in the nanoparticles with monomers [43].

Table 1. Antibiofilm activity of synthesized SV1 and SV2 ZrO nanoparticles.

\begin{tabular}{l|l|l}
$\begin{array}{l}\text { Oral Pathogenic } \\
\begin{array}{l}\text { Strain isolated } \\
\text { from human }\end{array}\end{array}$ & $\begin{array}{l}\text { Biofilm removal } \\
\% \text { for SV-1 }\end{array}$ & $\begin{array}{l}\text { Biofilm removal } \\
\% \text { for SV-2 }\end{array}$ \\
\hline Escherichia coli & 81 & 91.5 \\
\hline $\begin{array}{l}\text { Klebsiella } \\
\text { aerogenes }\end{array}$ & 62.5 & 71 \\
\hline Proteus vulgaris & 73.5 & 83.25 \\
\hline $\begin{array}{l}\text { Staphylococcus } \\
\text { aureus }\end{array}$ & 80.5 & 92.5 \\
\hline $\begin{array}{l}\text { Streptococcus } \\
\text { mutant }\end{array}$ & 83.5 & 90.5
\end{tabular}

\subsection{MTT assay.}

In Figure 6, MTT assay was done on human gingival fibroblasts (HGF) cell line, the biomaterial synthesized was found to be less toxicity and the viability was higher [44] the cell count was accepted to be in 94\% for SV1 [45]. In Figure 6 (b) and 98\% for SV2 in figure 6. (d). The morphological changes were not noticed and remain the same when compared with control cells [46]. In the graph, SV2 treatment reveals that at the higher concentration of 60 $\mu \mathrm{g} / \mathrm{ml}$ was treated to HGF. The viability percentage was slightly down to $94.34 \%$ when correlated with the lower concentration of $40 \mu \mathrm{g} / \mathrm{ml}$ by $98.18 \%$ [23]. The biomaterials are generally less toxic when used at the standard permissible limitation followed. With these standards, the biomaterials expose the valuable biological effects that promote biocompatibility and can be implemented in the drug delivery systems [47].
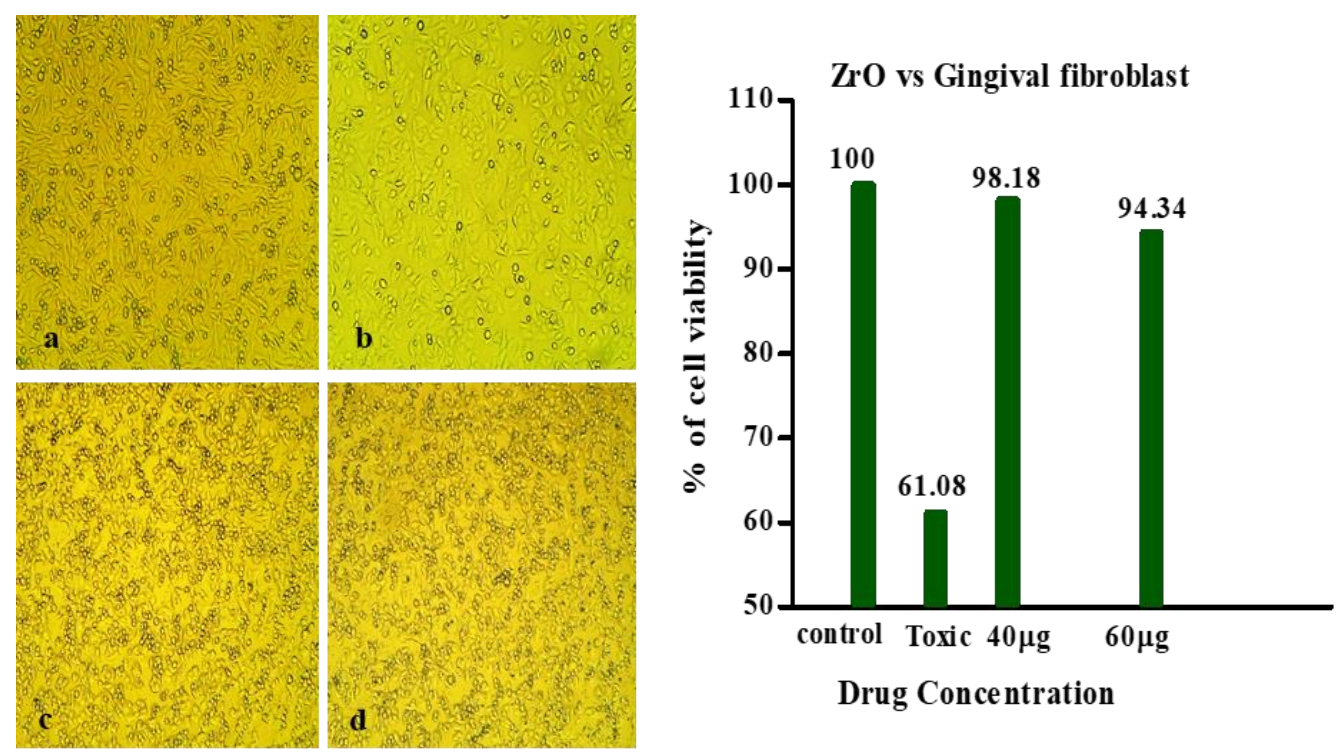

Figure 6. (a,b) Gingival fibroblast cells treated with SV1; (c,d) Gingival fibroblast cells treated with SV2. The graph represents the \% cell viability in the human gingival fibroblast cell line. 


\section{Conclusions}

Nowadays, generally, the dental crowns and restorative materials are made up of zirconia and titanium metals which are not favorable to microbial adhesion. The drawback of these materials was expensive. To overcome this financial crunch on the biomaterials, these kinds of biosynthetic zirconia materials can fetch up in combining both antibiofilm and dental restorative materials. Further in vivo studies have to be carried followed by the release mechanism of biogenic zirconium nanoparticles.

\section{Funding}

This research received no external funding.

\section{Acknowledgments}

The authors thank Vellore Institute of Technology Vellore for providing "VIT SEED GRANT" for carrying out this research work.

\section{Conflicts of Interest}

The authors declare no conflict of interest.

\section{References}

1. Mansoori, G.A.; Soelaiman, T.A.F. Nanotechnology - An introduction for the s1. Mansoori, G.A.; Soelaiman, T.A.F. Nanotechnology - An introduction for the standards community. J. ASTM Int. 2005, 2, 17-38, doi:10.1520/JAI13110.tandards community. J. ASTM Int. 2005, 2, 17-38, https://doi.org/10.1520/JAI13110.

2. Arreche, R.; Bellotti, N.; Blanco, M.; Vázquez, P. Synthesis and Characterization of Zirconium Oxides for Use as Antimicrobial Additives in Paints. Procedia Mater. Sci. 2015, 9, 627-634, https://doi.org/10.1016/j.mspro.2015.05.039.

3. Ramasamy, M.; Lee, J. Recent nanotechnology approaches for prevention and treatment of biofilm-associated infections on medical devices. Biomed Res. Int. 2016, 2016, https://doi.org/10.1155/2016/1851242.

4. Perera, W.P.T.D.; Dissanayake, R.K.; Ranatunga, U.I.; Hettiarachchi, N.M.; Perera, K.D.C.; Unagolla, J.M.; De Silva, R.T.; Pahalagedara, L.R. Curcumin loaded zinc oxide nanoparticles for activity-enhanced antibacterial and anticancer applications. RSC Adv. 2020, 10, 30785-30795, https://doi.org/10.1039/d0ra05755j.

5. Sundeep, D.; Vijaya Kumar, T.; Rao, P.S.S.; Ravikumar, R.V.S.S.N.; Gopala Krishna, A. Green synthesis and characterization of $\mathrm{Ag}$ nanoparticles from Mangifera indica leaves for dental restoration and antibacterial applications. Prog. Biomater. 2017, 6, 57-66, https://doi.org/10.1007/s40204-017-0067-9.

6. de Falco, B.; Amato, M.; Lanzotti, V. Chia seeds products: an overview. Phytochem. Rev. 2017, 16, 745760, https://doi.org/10.1007/s11101-017-9511-7.

7. Lee, J.; Nho, Y.H.; Yun, S.K.; Hwang, Y.S. Use of ethanol extracts of Terminalia chebula to prevent periodontal disease induced by dental plaque bacteria. BMC Complement. Altern. Med. 2017, 17, 1-10, https://doi.org/10.1186/s12906-017-1619-1.

8. Carounanidy, U.; Satyanarayanan, R.; Velmurugan, A. Use of an aqueous extract of Terminalia chebula as an anticaries agent: A clinical study. Indian J. Dent. Res. 2007, 18, 152-156, https://doi.org/10.4103/09709290.35823 .

9. Yadav, M.; Jain, S.; Tomar, R.; Prasad, G.B.K.S.; Yadav, H. Medicinal and biological potential of pumpkin: An updated review. Nutr. Res. Rev. 2010, 23, 184-190, https://doi.org/10.1017/S0954422410000107.

10. Golnaraghi Ghomi, A.R.; Mohammadi-Khanaposhti, M.; Vahidi, H.; Kobarfard, F.; Reza, M.A.S.; Barabadi, H. Fungus-mediated extracellular biosynthesis and characterization of zirconium nanoparticles using standard penicillium species and their preliminary bactericidal potential: A novel biological approach to nanoparticle synthesis. Iran. J. Pharm. Res. 2019, 18, 2101-2110, https://doi.org/10.22037/ijpr.2019.112382.13722.

11. Gherasim, O.; Puiu, R.A.; Bîrca, A.C.; Burduşel, A.C.; Grumezescu, A.M. An updated review on silver 
nanoparticles in biomedicine. Nanomaterials 2020, 10, https://doi.org/10.3390/nano10112318.

12. Dewhirst, F.E.; Chen, T.; Izard, J.; Paster, B.J.; Tanner, A.C.R.; Yu, W.H.; Lakshmanan, A.; Wade, W.G. The human oral microbiome. J. Bacteriol. 2010, 192, 5002-5017, https://doi.org/10.1128/JB.00542-10.

13. Baker, J.L.; Edlund, A. Exploiting the oral microbiome to prevent tooth decay: Has evolution already provided the best tools? Front. Microbiol. 2019, 10, 1-7, https://doi.org/10.3389/fmicb.2018.03323.

14. Roblin, R.O. Medicinal chemistry. Chem. Eng. News 1953, 31, 48-49, https://doi.org/10.1021/cenv031n001.p048.

15. Zarco, M.F.; Vess, T.J.; Ginsburg, G.S. The oral microbiome in health and disease and the potential impact on personalized dental medicine. Oral Dis. 2012, 18, 109-120, https://doi.org/10.1111/j.16010825.2011.01851.x.

16. Chimwamurombe, P.M.; Grönemeyer, J.L.; Reinhold-Hurek, B. Isolation and characterization of culturable seed-associated bacterial endophytes from gnotobiotically grown Marama bean seedlings. FEMS Microbiol. Ecol. 2016, 92, 1-11, https://doi.org/10.1093/femsec/fiw083.

17. Hernández-Sierra, J.F.; Galicia-Cruz, O.; Salinas-Acosta, A.; Ruíz, F.; Pierdant-Pérez, M.; Pozos-Guillén, A. In vitro cytotoxicity of silver nanoparticles on human periodontal fibroblasts. J. Clin. Pediatr. Dent. 2011, 36, 37-42, https://doi.org/10.17796/jcpd.36.1.d677647166398886.

18. Jangra, S.L.; Stalin, K.; Dilbaghi, N.; Kumar, S.; Tawale, J.; Singh, S.P.; Pasricha, R. Antimicrobial activity of zirconia (ZrO 2) nanoparticles and zirconium complexes. J. Nanosci. Nanotechnol. 2012, 12, 7105-7112, https://doi.org/10.1166/jnn.2012.6574.

19. Santhoshkumar, J.; Sowmya, B.; Venkat Kumar, S.; Rajeshkumar, S. Toxicology evaluation and antidermatophytic activity of silver nanoparticles synthesized using leaf extract of Passiflora caerulea. South African J. Chem. Eng. 2019, 29, 17-23, https://doi.org/10.1016/j.sajce.2019.04.001.

20. Khandel, P.; Kumar Shahi, S. Microbes mediated synthesis of metal nanoparticles: current status and future prospects. Int. J. Nanomater. Biostructures 2016, 6, 1-24.

21. Balaji, S.; Mandal, B.K.; Ranjan, S.; Dasgupta, N.; Chidambaram, R. Nano-zirconia - Evaluation of its antioxidant and anticancer activity. J. Photochem. Photobiol. B Biol. 2017, 170, 125-133, https://doi.org/10.1016/j.jphotobiol.2017.04.004.

22. Yusof, H.M.; Rahman, N.A.; Mohamad, R.; Zaidan, U.H. Microbial mediated synthesis of silver nanoparticles by lactobacillus plantarum ta 4 and its antibacterial and antioxidant activity. Appl. Sci. 2020, 10, 1-18, https://doi.org/10.3390/app10196973.

23. Karimzadeh, M.R.; Soltanian, S.; Sheikhbahaei, M.; Mohamadi, N. Characterization and biological activities of synthesized zinc oxide nanoparticles using the extract of Acantholimon serotinum. Green Process. Synth. 2020, 9, 722-733, https://doi.org/10.1515/gps-2020-0058.

24. Hu, C.; Sun, J.; Long, C.; Wu, L.; Zhou, C.; Zhang, X. Synthesis of nano zirconium oxide and its application in dentistry. Nanotechnol. Rev. 2019, 8, 396-404, https://doi.org/10.1515/ntrev-2019-0035.

25. Guerreiro-Tanomaru, J.M.; Trindade-Junior, A.; Cesar Costa, B.; Da Silva, G.F.; Drullis Cifali, L.; Basso Bernardi, M.I.; Tanomaru-Filho, M. Effect of Zirconium Oxide and Zinc Oxide Nanoparticles on Physicochemical Properties and Antibiofilm Activity of a Calcium Silicate-Based Material. Sci. World J. 2014, 2014, https://doi.org/10.1155/2014/975213.

26. Mitwalli, H.; Alsahafi, R.; Balhaddad, A.A.; Weir, M.D.; Xu, H.H.K.; Melo, M.A.S. Emerging contact-killing antibacterial strategies for developing anti-biofilm dental polymeric restorative materials. Bioengineering 2020, 7, 1-25, https://doi.org/10.3390/bioengineering7030083.

27. Shaalan, O.O.; Abou-Auf, E.; Farid El Zoghby, A. Clinical evaluation of self-adhering flowable composite versus conventional flowable composite in conservative Class I cavities: Randomized controlled trial. J. Conserv. Dent. 2018, 21, 485-490, https://doi.org/10.4103/JCD.JCD_210_18.

28. Illeperuma, R.P.; Kim, J.; Park, Y.J.; Kim, J.M.; Bae, J.Y.; Che, Z.M.; Son, H.K.; Han, M.R.; Kim, K.M. Immortalized gingival fibroblasts as a cytotoxicity test model for dental materials. J. Mater. Sci. Mater. Med. 2012, 23, 753-762, https://doi.org/10.1007/s10856-011-4473-6.

29. Horti, N.C.; Kamatagi, M.D.; Nataraj, S.K.; Wari, M.N.; Inamdar, S.R. Structural and optical properties of zirconium oxide (ZrO 2 ) nanoparticles: effect of calcination temperature . Nano Express 2020, 1, 010022, https://doi.org/10.1088/2632-959x/ab8684.

30. Chowdhary, S.; Felicita, A.S.; Shanmugam, R. Antimicrobial Assay of Novel Zirconia and Silver Phyto Nanoparticles Biosynthesized using Ocimum Sanctum and Syzygium Aromaticum Extract-A Preliminary Study. J. Res. Med. Dent. Sci. 2020, 8, 33-36.

31. Das, D.; Nath, B.C.; Phukon, P.; kalita, A.; Dolui, S.K. Synthesis of ZnO nanoparticles and evaluation of 
antioxidant and cytotoxic activity. Colloids Surfaces B Biointerfaces 2013, 111, 556-560, https://doi.org/10.1016/j.colsurfb.2013.06.041.

32. Al-Zaqri, N.; Muthuvel, A.; Jothibas, M.; Alsalme, A.; Alharthi, F.A.; Mohana, V. Biosynthesis of zirconium oxide nanoparticles using Wrightia tinctoria leaf extract: Characterization, photocatalytic degradation and antibacterial activities. Inorg. Chem. Commun. 2021, 127, 108507 , https://doi.org/10.1016/j.inoche.2021.108507.

33. Gopinath, K.; Gowri, S.; Karthika, V.; Arumugam, A. Green synthesis of gold nanoparticles from fruit extract of Terminalia arjuna, for the enhanced seed germination activity of Gloriosa superba. J. Nanostructure Chem. 2014, 4, https://doi.org/10.1007/s40097-014-0115-0.

34. Majedi, A.; Abbasi, A.; Davar, F. Green synthesis of zirconia nanoparticles using the modified Pechini method and characterization of its optical and electrical properties. J. Sol-Gel Sci. Technol. 2016, 77, 542552, https://doi.org/10.1007/s10971-015-3881-3.

35. Vemuri, P.K.; Dronavalli, L.; Nayakudugari, P.; Kunta, A.; Challagulla, R. Phytochemical analysis and biochemical characterization of Terminalia chebula extracts for its medicinal use. Biomed. Pharmacol. J. 2019, 12, 1525-1529, https://doi.org/10.13005/bpj/1783.

36. Castronovo, L.M.; Vassallo, A.; Mengoni, A.; Miceli, E.; Bogani, P.; Firenzuoli, F.; Fani, R.; Maggini, V. Medicinal plants and their bacterial microbiota: A review on antimicrobial compounds production for plant and human health. Pathogens 2021, 10, 1-17, https://doi.org/10.3390/pathogens10020106.

37. Liu, Z.; Wang, Y.; Jia, X.; Lu, W. Isolation of Secondary Metabolites with Antimicrobial Activities from Bacillus amyloliquefaciens LWYZ003. Trans. Tianjin Univ. 2019, 25, 38-44, https://doi.org/10.1007/s12209-018-0137-7.

38. Lee, D.W.; Park, Y.W.; Lee, M.Y.; Jeong, K.H.; Lee, J.Y. Structural analysis and insight into effector binding of the niacin-responsive repressor NiaR from Bacillus halodurans. Sci. Rep. 2020, 10, 1-8, https://doi.org/10.1038/s41598-020-78148-X.

39. Diriba, K.; Kassa, T.; Alemu, Y.; Bekele, S. In Vitro Biofilm Formation and Antibiotic Susceptibility Patterns of Bacteria from Suspected External Eye Infected Patients Attending Ophthalmology Clinic, Southwest Ethiopia. Int. J. Microbiol. 2020, 2020, https://doi.org/10.1155/2020/8472395.

40. Jiang, Y.; Geng, M.; Bai, L. Targeting biofilms therapy: Current research strategies and development hurdles. Microorganisms 2020, 8, 1-34, https://doi.org/10.3390/microorganisms8081222.

41. Wu, X.; Al Farraj, D.A.; Rajaselvam, J.; Alkufeidy, R.M.; Vijayaraghavan, P.; Alkubaisi, N.A.; Agastian, P.; Alshammari, M.K. Characterization of biofilm formed by multidrug resistant Pseudomonas aeruginosa DC17 isolated from dental caries. Saudi J. Biol. Sci. 2020, 27, 2955-2960, https://doi.org/10.1016/j.sjbs.2020.07.020.

42. Yi, L.; Jin, M.; Li, J.; Grenier, D.; Wang, Y. Antibiotic resistance related to biofilm formation in Streptococcus suis. Appl. Microbiol. Biotechnol. 2020, 104, 8649-8660, https://doi.org/10.1007/s00253-02010873-9.

43. Chen, X; Daliri, E.B.M.; Kim, N.; Kim, J.R.; Yoo, D.; Oh, D.H. Microbial etiology and prevention of dental caries: Exploiting natural products to inhibit cariogenic biofilms. Pathogens 2020, 9, 1-15, https://doi.org/10.3390/pathogens9070569.

44. Kavuncu, G.; Yilmaz, A.M.; Yilmaz, B.K.; Atali, P.Y.; Altunok, E.C.; Kuru, L.; Agrali, O.B. Cytotoxicity of different nano composite resins on human gingival and periodontal ligament fibroblast cell lines: An in vitro study. Biomedicines 2020, 8, https://doi.org/10.3390/biomedicines8030048.

45. Krismariono, A.; Ulfa, N.; Wardi, U.N.; Budijono, S.C.S. Viability test of water hyacinth leaf extract (Eichornia Crassipes) on human gingival fibroblast cell culture. AIP Conference Proceedings 2020, 2314, 060014.

46. Youssef, A.R.; Alturkistani, E.; Muharrij, I.; Alsrehi, L.; Shafei, N.; Alzahrani, N.; Alqahtani, M. Effects of chlorhexidine, ethylenediaminetetraacetic acid, and sodium hypochlorite on cell viability of human gingival fibroblasts in vitro. Saudi Endod. J. 2020, 10, 234-239, https://doi.org/10.4103/sej.sej_149_19.

47. Alaki, S.; Abdulhadi, B.; Abdullah, M.; Al-Alamoudi, N. Comparing Zirconia to Anterior Strip Crowns: A Randomized Clinical Trial. 2020, 1-18, https://doi.org/10.21203/rs.3.rs-38319/v1. 